\title{
Optimization Model for Effective Implementation of the Recommendations From Research Findings in the Field of Education Management
}

\author{
Widodo Sunaryo*, Soewarto Hardhienata, Herfina \\ Post-Graduate Program \\ Pakuan University \\ Bogor, Indonesia \\ *widodos.unpak@yahoo.com
}

\begin{abstract}
Many research findings in the field of Education Management cannot be implemented effectively. The problem derived from the fact that many research findings generated recommendation which still focus on normative and theoretical orientation. Despite that, the organizations, where research took place, mostly had limited resources that became constraints for implementing too many recommendations from research findings. This paper elaborated the development of an optimization model for effective implementation of the recommendations from research findings. The basic idea of this model coming from the core-concept of optimization that is starting and focusing to analyse the recommendations from research findings, more specially to identify indicators of research variables which have priority to be improved or to be maintained. The identification process of those indicators using the concept of "Scientific Identification Theory to Conduct Operation Research in Education Management (SITOREM)". The concept of SITOREM consist of assessment process using some criteria to rank indicators of the variables from the highest to the lowest level in term of priority. The criteria used are in terms of Costs, Benefits, Urgent and Importance (CBUI Criteria). It means that indicators which met the criteria of Cost, Benefits, Urgent and Important will have high priority to be optimized when they were implemented in organizational setting.
\end{abstract}

Keywords-optimization model, priority rank of indicators, SITOREM concept, CBUI criteria

\section{INTRODUCTION}

Many of research in Education Management had highly concerned for examining the research hypotheses through statistical analysis. It looked like that the objectives of the research just how to find the way to examine the hypotheses. The recommendations to implement the research findings had just given in theoretical terms. Those research less concerned to elaborate and formulate how the research findings should be effectively implemented. Consequently, the recommendations given less concerned to the actual resources of the organizations where research took place. Also, the research findings produced by universities, research institutes, schools, and practitioners have not been optimally disseminated and utilized and have not produce maximum impact on the improvement of quality of life.

In operationalizing this model, we use the SITOREM Concept that used to identify the indicators of research variables and use some wise-pair factors as criteria (CBUI) to analyse the actual condition of the organization. Based on the results from operationalizing the SITOREM and CBUI Criteria, it can be identified the priority of indicators which have to be improved and maintained.

When the priority of indicators (from each research variables) can be identified which ones have to be improved and maintained, then the organizations (where the research took place) can easily decide which indicators have to be improved right away regarding the available resources. It means that the research finding will have the recommendation that not just in theoretical orientation but will be optimum, efficient and effective for the organizations.

This paper proposed a model of optimization for implementing research findings in efficient and effective manner. The basic idea of this model coming from the concept of optimization. The objectives of this optimization model are to find out how to determine optimum solution in implementing the research findings and to use available resources in the most efficient and effective manner.

\section{THE THEORY OF SITOREM}

Sarker and Newton [1] stated that the basic concept of optimization is to find the best possible solution to a given problem. In operational setting, this concept can be used as an approach to find the way how the resource of the organization can be used in the most economical manners. Kelly [2] describe the optimization process as a technique to determine optimum solutions to problem. The optimization process should start from the design (planning) stage that is the systematic process using design and criteria to allow the designer to locate the optimal solution. It means that it become 
optimum when design and criteria "doing the most with the least".

Based on the optimization concept, Hardhienata [3] developed a model to conduct operation research in education management that named SITOREM (Scientific Identification Theory to Conduct Operation Research in Education Management) (in Figure 1).

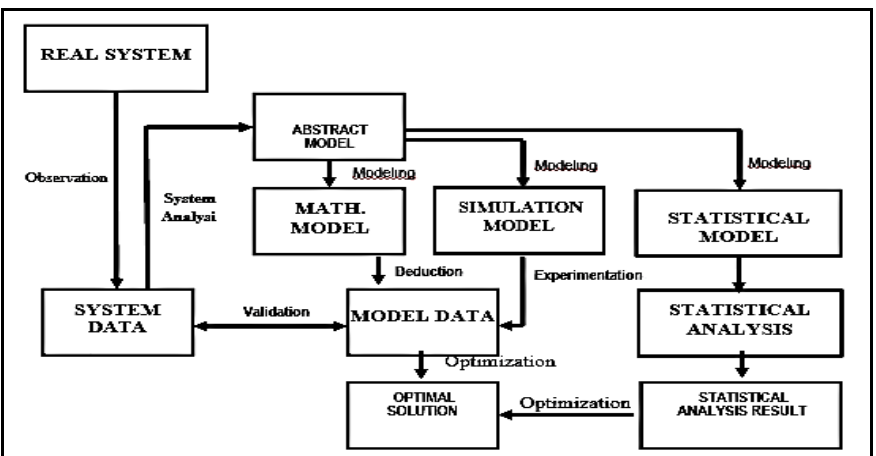

Fig. 1. Theoretical model of SITOREM.

The main objective of using SITOREM in Education Management research is to generate recommendations to implement research findings based on priority ranking. Hardhienata [3] suggest that priority ranking must consider 3 aspects, those are (1) the strength of correlation coefficient between independent and dependent variables, (2) the score of indicators of each independent and dependent variables derived from the research instruments, and (3) the scores of each indicator derived from actual condition in the research setting.

In recent years, SITOREM Method had been utilized in much research in Education Management. Sunaryo et al. [4] had utilized SITOREM Analysis to investigate the optimization of enhancement the organizational commitment through developing organizational culture and interpersonal communication. Fauziah et al. [5], had utilized SITOREM analysis in the research of improvement organizational citizenship behaviour through personality, interpersonal communication, and organizational justice. Rosandi et al. [6] had utilized SITOREM Analysis in their research of improvement organizational citizenship behaviour (OCB) through strengthening transformational leadership, job satisfaction, and self-efficacy. Djami et al. [7] had utilized SITOREM Analysis to study the improvement of job satisfaction through transformational leadership, personality, and achievement motivation. Dasmin et al. [8] had utilized SITOREM Analysis to study the improving teacher performance through organizational culture, transformational leadership and work motivation.

\section{THE EXAMPLE OF IMPLEMENTING SITOREM CONCEPT}

The first and the second aspects of the SITOREM, those are coefficient correlation and scores of indicators, can be showed in an example of a research of the relationship between Service Quality, Organizational Citizenship Behaviour and Training Program with Innovation as describe in Figure 2.

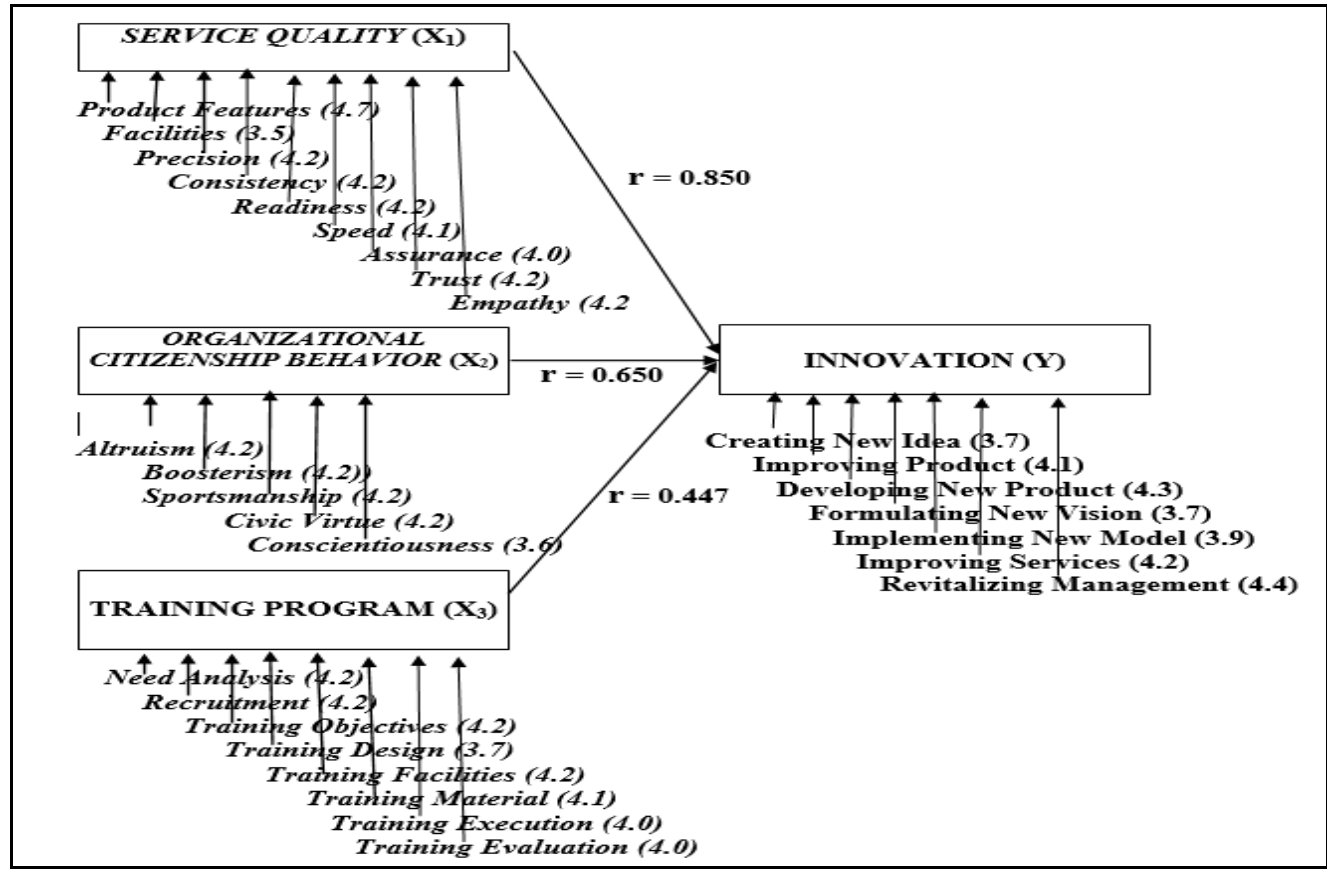

Fig. 2. An example of relationship between research variables (the correlation of variables \& scores of indicators).

The next question is how to obtain the third aspect that is scores of indicators derived from actual condition in the research setting. Recently, Sunaryo and Setyaningsih [9] developed an appraisal method for estimating the actual condition of each indicator in the research setting. This method using an Expert Judgment Technique to appraise the actual 
condition of each indicator by applying Costs, Benefits, Urgent and Importance (CIBU) criteria.

Let we use the example variable above mentioned to describe the Expert Judgment process. We appointed an Expert to appraise each indicator by applying CIBU Criteria used a 15 Likert Scale (score 1: Very Unsatisfactory, score 2: Unsatisfactory, score 3: Less Satisfactory, score 4: Almost Satisfactory, and score 5: Satisfactory). In that case, an appointed expert must have high educational background and intensive experiences in Education Management or Educational Administration. The Criteria of Costs are expenses, efforts or resources needed in that indicator. The higher expenses, efforts or resources needed means the higher role this indicator in the variable. The Criteria of Benefits (Ben) are usage, contribution or goodness of the indicator. The higher Benefits of indicator means the higher role of this indicator in the variable. The Criteria of Urgency (Urg) are urge, drive, or demand of an indicator in the variable. The higher Urgency means the higher role of this indicator in the variable. The Criteria of Importance (Imp) are necessity or critical role of an indicator in the variable. The higher Importance means the higher role of this indicator in the variable. The example of Expert Judgment results can be described in the tables below (The Weighted Percentage described the relative composition strength of each indicator in each variable).

TABLE I. SCORES OF INNOVATION FROM EXPERT JUDGMENT

\begin{tabular}{|l|l|l|l|l|l|l|l|}
\hline \multirow{2}{*}{ No } & \multirow{2}{*}{ Indicator } & \multicolumn{5}{|c|}{$\begin{array}{c}\text { Scores From Expert } \\
\text { Judgment }\end{array}$} & \multirow{2}{*}{$\begin{array}{c}\text { Total } \\
\text { (\%) }\end{array}$} \\
\cline { 3 - 7 } & & Cost & Ben & Urg & Imp & & \\
\hline 1 & Creating New Idea & 2 & 1 & 1 & 2 & 6 & 12 \\
\hline 2 & Improving Product & 0 & 0 & 0 & 0 & 7 & 14 \\
\hline 3 & $\begin{array}{l}\text { Developing New } \\
\text { Product }\end{array}$ & 2 & 2 & 1 & 2 & 7 & 14 \\
\hline 4 & $\begin{array}{l}\text { Formulating New } \\
\text { Vision }\end{array}$ & 1 & 1 & 1 & 1 & 4 & 8 \\
\hline 5 & $\begin{array}{l}\text { Implementing New } \\
\text { Model }\end{array}$ & 0 & 1 & 0 & 0 & 6 & 12 \\
\hline 6 & $\begin{array}{l}\text { Improving } \\
\text { Services }\end{array}$ & 2 & 4 & 4 & 5 & 15 & 32 \\
\hline 7 & $\begin{array}{l}\text { Revitalizing } \\
\text { Management }\end{array}$ & 1 & 1 & 1 & 1 & 4 & 8 \\
\hline T O T A L & & & & & 49 & $100 \%$ \\
\hline
\end{tabular}

TABLE II. SCORES OF SERVICE QUALITY FROM EXPERT JUDGMENT

\begin{tabular}{|c|c|c|c|c|c|c|c|}
\hline \multirow[t]{2}{*}{ No } & \multirow[t]{2}{*}{ Indicator } & \multicolumn{4}{|c|}{$\begin{array}{c}\text { Scores From Expert } \\
\text { Judgment }\end{array}$} & \multirow[t]{2}{*}{ Total } & \multirow[t]{2}{*}{$\begin{array}{c}\text { Weighted } \\
(\%)\end{array}$} \\
\hline & & Cost & Ben & Urg & Imp & & \\
\hline 1 & Product Features & 3 & 2 & 2 & 4 & 11 & 17 \\
\hline 2 & Facilities & 5 & 5 & 5 & 5 & 20 & 30 \\
\hline 3 & Precision & 1 & 2 & 1 & 3 & 7 & 11 \\
\hline 4 & Consistency & 0 & 1 & 1 & 1 & 3 & 4.5 \\
\hline 5 & Readiness & 1 & 2 & 1 & 3 & 7 & 11 \\
\hline 6 & Speed & 3 & 1 & 1 & 3 & 8 & 12 \\
\hline 7 & Assurance & 0 & 1 & 0 & 1 & 2 & 3 \\
\hline 8 & Trust & 0 & 1 & 1 & 1 & 3 & 4.5 \\
\hline 9 & Empathy & 1 & 1 & 1 & 2 & 5 & 7 \\
\hline \multicolumn{6}{|c|}{ TO T A L } & 66 & $100 \%$ \\
\hline
\end{tabular}

TABLE III. SCORES OF ORGANIZATIONAL CITIZENSHIP BEHAVIOR FROM EXPERT JUDGMENT

\begin{tabular}{|c|c|c|c|c|c|c|c|}
\hline \multirow[t]{2}{*}{ No } & \multirow[t]{2}{*}{ Indicator } & \multicolumn{4}{|c|}{$\begin{array}{c}\text { Scores From Expert } \\
\text { Judgment }\end{array}$} & \multirow[t]{2}{*}{ Total } & \multirow[t]{2}{*}{$\begin{array}{l}\text { Weighted } \\
(\%)\end{array}$} \\
\hline & & Cost & Ben & Urg & Imp & & \\
\hline 1 & Altruism & 2 & 4 & 4 & 5 & 15 & 24 \\
\hline 2 & Sportmanship & 2 & 2 & 2 & 3 & 9 & 14 \\
\hline 3 & Civic Virtue & 2 & 3 & 3 & 5 & 13 & 20 \\
\hline 4 & Conscientiousness & 3 & 5 & 4 & 5 & 17 & 27 \\
\hline 5 & Boosterism & 2 & 2 & 3 & 3 & 10 & 15 \\
\hline \multicolumn{6}{|c|}{ TO T A L } & 64 & $100 \%$ \\
\hline
\end{tabular}

TABLE IV. SCORES OF TRAINING PROGRAM FROM EXPERT JUDGMENT

\begin{tabular}{|c|c|c|c|c|c|c|c|}
\hline \multirow[t]{2}{*}{ No } & \multirow[t]{2}{*}{ Indicator } & \multicolumn{4}{|c|}{$\begin{array}{c}\text { Scores From Expert } \\
\text { Judgment }\end{array}$} & \multirow[t]{2}{*}{ Total } & \multirow[t]{2}{*}{$\begin{array}{c}\text { Weighted } \\
(\%)\end{array}$} \\
\hline & & Cost & Ben & Urg & Imp & & \\
\hline 1 & Need Analysis & 2 & 4 & 3 & 5 & 14 & 17 \\
\hline 2 & Recruitment & 1 & 2 & 2 & 2 & 7 & 9 \\
\hline 3 & $\begin{array}{l}\text { Training } \\
\text { Objectives } \\
\end{array}$ & 1 & 1 & 2 & 4 & 8 & 10 \\
\hline 4 & Training Design & 3 & 3 & 3 & 3 & 12 & 15 \\
\hline 5 & Training Facilities & 1 & 4 & 1 & 2 & 8 & 10 \\
\hline 6 & Training Material & 3 & 1 & 1 & 2 & 7 & 9 \\
\hline 7 & Training Execution & 3 & 5 & 3 & 5 & 16 & 20 \\
\hline 8 & $\begin{array}{l}\text { Training } \\
\text { Evaluation }\end{array}$ & 1 & 3 & 1 & 3 & 8 & 10 \\
\hline \multicolumn{6}{|c|}{ TO T A L } & 80 & $100 \%$ \\
\hline
\end{tabular}

The next step of SITOREM is to combine the scores from research setting and the scores from Expert Judgment for each variable. The objective of this step is to make a classification of the data from the research instruments and the judgment from the Expert. It assumes that by its classification the research findings will be more connected to the actual condition of the organizations. Those combined scores from expert and scores from research described in Table 5 below. In that case, indicators which had score from research 4 or higher (Almost Satisfactory and Satisfactory) were classified as "To be maintained". Indicators which had score 3 or lower (Less Satisfactory, Unsatisfactory and Very Unsatisfactory) were classified "To be improved".

TABLE V. CLASSIFICATION OF INNOVATION INDICATORS

\begin{tabular}{|l|l|l|l|l|}
\hline No & $\begin{array}{l}\text { Indicators of } \\
\text { Innovation }\end{array}$ & $\begin{array}{l}\text { Weighted (\%) } \\
\text { from Expert } \\
\text { (Table 1) }\end{array}$ & $\begin{array}{l}\text { Scores from } \\
\text { Research } \\
\text { (Figure 2) }\end{array}$ & $\begin{array}{c}\text { Classification of } \\
\text { Indicators }\end{array}$ \\
\hline 1 & $\begin{array}{l}\text { Creating new } \\
\text { idea }\end{array}$ & 12 & 3.7 & $\begin{array}{l}(12 \%)(3.7) \text { indicator } \\
\text { to be improved }\end{array}$ \\
\hline 2 & $\begin{array}{l}\text { Improving } \\
\text { product }\end{array}$ & 14 & 4.1 & $\begin{array}{l}(14 \%)(4.1) \text { indicator } \\
\text { to be maintained }\end{array}$ \\
\hline 3 & $\begin{array}{l}\text { Developing } \\
\text { new product }\end{array}$ & 14 & 4.3 & $\begin{array}{l}(14 \%)(4.3): \text { indicator } \\
\text { to be maintained }\end{array}$ \\
\hline 4 & $\begin{array}{l}\text { Formulating } \\
\text { new vision }\end{array}$ & 8 & 3.7 & $\begin{array}{l}(8 \%)(3.7) \text { indicator to } \\
\text { be improved }\end{array}$ \\
\hline 5 & $\begin{array}{l}\text { Implementing } \\
\text { new model }\end{array}$ & 12 & 3.9 & $\begin{array}{l}(12 \%)(3.9): \text { indicator } \\
\text { to be improved }\end{array}$ \\
\hline 6 & $\begin{array}{l}\text { Improving } \\
\text { services }\end{array}$ & 32 & 4.2 & $\begin{array}{l}(8 \%)(3.7): \text { indicator to } \\
\text { be maintained }\end{array}$ \\
\hline 7 & $\begin{array}{l}\text { Revitalizing } \\
\text { management }\end{array}$ & 8 & 4.4 & $\begin{array}{l}(2 \%)(3.9): \text { indicator to } \\
\text { be maintained }\end{array}$ \\
\hline & \multicolumn{2}{|l}{} & & \\
\hline
\end{tabular}


TABLE VI. Classification OF SERVICE Quality INDICATORS

\begin{tabular}{|l|l|l|l|l|}
\hline No & $\begin{array}{l}\text { Indicators of } \\
\text { Service } \\
\text { Quality }\end{array}$ & $\begin{array}{c}\text { Weighted (\%) } \\
\text { from Expert } \\
\text { (Table 2) }\end{array}$ & $\begin{array}{l}\text { Scores from } \\
\text { Research } \\
\text { (Figure 2) }\end{array}$ & $\begin{array}{c}\text { Classification of } \\
\text { Indicators }\end{array}$ \\
\hline 1 & $\begin{array}{l}\text { Product } \\
\text { features }\end{array}$ & 17 & 4.7 & $\begin{array}{l}(17 \%)(4.7): \text { indicator } \\
\text { to be maintained }\end{array}$ \\
\hline 2 & Facilities & 30 & 3.5 & $\begin{array}{l}(30 \%)(3.5): \text { indicator } \\
\text { to be improved }\end{array}$ \\
\hline 3 & Precision & 11 & 4.2 & $\begin{array}{l}(11 \%)(4.2): \text { indicator } \\
\text { to be maintained }\end{array}$ \\
\hline 4 & Consistency & 4.5 & 4.2 & $\begin{array}{l}(4.5 \%)(4.2): \text { indicator } \\
\text { to be maintained }\end{array}$ \\
\hline 5 & Readiness & 11 & 4.2 & $\begin{array}{l}(11 \%)(4.2): \text { indicator } \\
\text { to be maintained }\end{array}$ \\
\hline 6 & Speed & 12 & 4.1 & $\begin{array}{l}(12 \%)(4.1): \text { indicator } \\
\text { to be maintained }\end{array}$ \\
\hline 7 & Assurance & 3 & 4.0 & $\begin{array}{l}(3 \%)(4.0): \text { indicator } \\
\text { to be maintained }\end{array}$ \\
\hline 8 & Trust & 4.5 & 4.2 & $\begin{array}{l}(4.4 \%)(4.2): \text { indicator } \\
\text { to be maintained }\end{array}$ \\
\hline 9 & Empathy & 7 & 4.2 & $\begin{array}{l}(7 \%)(4.1): \text { indicator } \\
\text { to be maintained }\end{array}$ \\
\hline & & $100 \%$ & & \\
\hline
\end{tabular}

TABLE VII. CLASSIFICATION OF OCB INDICATORS

\begin{tabular}{|l|l|l|l|l|}
\hline No & $\begin{array}{c}\text { Indicators of } \\
\text { Organizational } \\
\text { Citizenship } \\
\text { Behaviour (OCB) }\end{array}$ & $\begin{array}{c}\text { Weighted } \\
\text { (\%) from } \\
\text { Expert } \\
\text { (Table 3) }\end{array}$ & $\begin{array}{c}\text { Scores } \\
\text { from } \\
\text { Research } \\
\text { (Figure 2) }\end{array}$ & $\begin{array}{c}\text { Classification of } \\
\text { Indicators }\end{array}$ \\
\hline 1 & Altruism & 24 & 4.2 & $\begin{array}{l}(24 \%)(4.2): \text { indicator } \\
\text { to be maintained }\end{array}$ \\
\hline 2 & Sportmanship & 14 & 4.2 & $\begin{array}{l}(14 \%)(4.2): \text { indicator } \\
\text { to be maintained }\end{array}$ \\
\hline 3 & Civic virtue & 20 & 4.2 & $\begin{array}{l}(20 \%)(4.2): \text { indicator } \\
\text { to be maintained }\end{array}$ \\
\hline 4 & Conscientiousness & 27 & 4.2 & $\begin{array}{l}(27 \%)(4.2): \text { indicator } \\
\text { to be maintained }\end{array}$ \\
\hline 5 & Boosterism & 15 & 3.6 & $\begin{array}{l}(15 \%)(3.6): \text { indicator } \\
\text { to be improved }\end{array}$ \\
\hline & & $100 \%$ & & \\
\hline
\end{tabular}

TABLE VIII. ClasSIFICATION OF TRAINING PROGRAM INDICATORS

\begin{tabular}{|l|l|l|l|l|}
\hline No & $\begin{array}{c}\text { Indicators of } \\
\text { Training } \\
\text { Program }\end{array}$ & $\begin{array}{c}\text { Weighted } \\
\left(\begin{array}{c}\text { \%) from } \\
\text { Expert } \\
\text { Table 4) }\end{array}\right.\end{array}$ & $\begin{array}{c}\text { Scores } \\
\text { from } \\
\text { Research } \\
\text { (Figure 2) }\end{array}$ & \multicolumn{1}{|c|}{$\begin{array}{c}\text { Classification of } \\
\text { Indicators }\end{array}$} \\
\hline 1 & Need analysis & 17 & 4.2 & $\begin{array}{l}(17 \%)(4.2): \text { indicator to } \\
\text { be maintained }\end{array}$ \\
\hline 2 & Recruitment & 9 & 4.2 & $\begin{array}{l}(9 \%)(4.2): \text { indicator to } \\
\text { be maintained }\end{array}$ \\
\hline 3 & $\begin{array}{l}\text { Training } \\
\text { objectives }\end{array}$ & 10 & 4.2 & $\begin{array}{l}(10 \%)(4.2): \text { indicator to } \\
\text { be maintained }\end{array}$ \\
\hline $\mathbf{4}$ & Training design & $\mathbf{1 5}$ & $\mathbf{3 . 7}$ & $\begin{array}{l}(\mathbf{1 5 \%})(\mathbf{3 . 7}) \text { indicator } \\
\text { to be improved }\end{array}$ \\
\hline 5 & Training facilities & 10 & 4.2 & $\begin{array}{l}(10 \%)(4.2): \text { indicator to } \\
\text { be maintained }\end{array}$ \\
\hline 6 & Training material & 9 & 4.1 & $\begin{array}{l}(9 \%)(4.1): \text { indicator to } \\
\text { be maintained }\end{array}$ \\
\hline 7 & $\begin{array}{l}\text { Training } \\
\text { execution }\end{array}$ & 20 & 4.0 & $\begin{array}{l}(20 \%)(4.0): \text { indicator to } \\
\text { be maintained }\end{array}$ \\
\hline 8 & $\begin{array}{l}\text { Training } \\
\text { evaluation }\end{array}$ & 10 & 4.0 & $\begin{array}{l}(10 \%)(4.0): \text { indicator to } \\
\text { be maintained }\end{array}$ \\
\hline & & $100 \%$ & & \\
\hline
\end{tabular}

Based on data in Table 1 to 8 , it can be concluded the SITOREM results as described in the table below.

TABLE IX. SITOREM ANALYSIS RESULTS

\begin{tabular}{|c|c|c|}
\hline \multicolumn{3}{|c|}{ Variable: Innovation } \\
\hline $\begin{array}{l}\text { Rank of Indicator in Initial } \\
\text { State }\end{array}$ & Rank of Indicator after Weighting & $\begin{array}{l}\text { Indicator } \\
\text { Value }\end{array}$ \\
\hline Creating New Idea & 1. Improving Service (32\%) & 4.2 \\
\hline Improving Product & 2. Improving Product $(14 \%)$ & 4.1 \\
\hline Developing New Product & 3. Developing New Product (14\%) & 4.3 \\
\hline Formulating New Vision & 4. Creating New Idea $(12 \%)$ & 3.7 \\
\hline Implementing New Model & 5.Implementing New Model (12\%) & 3.9 \\
\hline Improving Services & 6. Formulating New Vision $(8 \%)$ & 3.7 \\
\hline Revitalizing Management & 7. Revitalizing Management ( $8 \%)$ & 4.4 \\
\hline \multicolumn{3}{|c|}{ Variable: Service Quality } \\
\hline Product Feature & 1. Facilities $(30 \%)$ & 3.5 \\
\hline Facilities & 2. Product Feature $(17 \%)$ & 4.7 \\
\hline Precision & 3. Speed $(12 \%)$ & 4.1 \\
\hline Consistency & 4. Precision $(11 \%)$ & 4.2 \\
\hline Readiness & 5. Readiness (7\%) & 4.2 \\
\hline Speed & 6. Empathy $(7 \%)$ & 4.2 \\
\hline Assurance & 7. Consistency $(7 \%)$ & 4.2 \\
\hline Trust & 8. Trust $(7 \%)$ & 4.2 \\
\hline Empathy & 9. Assurance (3\%) & 4.0 \\
\hline \multicolumn{3}{|c|}{ Variable: Organizational Citizenship Behaviour } \\
\hline Altruism & 1. Conscientiousness $(27 \%)$ & 3.6 \\
\hline Boosterism & 2. Altruism (24\%) & 4.2 \\
\hline Sportmanship & 3. Civic Virtue (20\%) & 4.2 \\
\hline Civic Virtue & 4. Boosterism (15\%) & 4.2 \\
\hline Conscientiousness & 5. Sportmanship (14\%) & 4.2 \\
\hline \multicolumn{3}{|c|}{ Variable: Training Program } \\
\hline Training Need Analysis & 1. Training Execution $(20 \%)$ & 4.0 \\
\hline Recruitment & 2. Training Need Analysis (17\%) & 4.2 \\
\hline Training Objective & 3. Training Design (15\%) & 3.7 \\
\hline Training Design & 4. Training Objective (10\%) & 4.2 \\
\hline Training Facilities & 5. Training Facilities (10\%) & 4.2 \\
\hline Training Material & 6. Training Evaluation $(10 \%)$ & 4.0 \\
\hline Training Execution & 7. Recruitment $(9 \%)$ & 4.2 \\
\hline Training Evaluation & 8. Training Material (9\%) & 4.1 \\
\hline \multicolumn{3}{|c|}{ FINAL RESULTS OF SITOREM ANALYSIS } \\
\hline $\begin{array}{l}\text { Priority Order Indicators } \\
\text { to be Improved }\end{array}$ & Indicators Remain to be Maintained & \\
\hline
\end{tabular}

The results of SITOREM Analysis (Table 9) had specifically shown that there were some indicators such as facilities (from Service Quality variable), Altruism (from OCB Variable), training objective (from Training Program variable), creating new ideas, formulating new vision, and implementing new model (from Innovation variable) that needed to be improved. This study had listed the priority order of those indicators to be improved. The other indicators had been categorized as Indicators Remain to be maintained because those indicators are still in a good condition and become strong points for the organizations.

The results of SITOREM Analysis become a recommendation for organizations to decide which indicators 
must improve first, second, third, and soon, as well as which indicators must be maintained or developed.

\section{CONCLUSION AND RECOMMENDATION}

The SITOREM analysis developed through the concept of optimization that is to find the best possible solution to a given problem. In operational setting, this concept can be used as an approach to find the way how the resource of the organization can be used in the most economical manners. The results of SITOREM Analysis described the list of indicators that recommended to be improved in priority order and indicators that recommended to be maintained. It means that not all indicators of the variables are needed to be improved simultaneously and organizations can take decisions which indicators have to be improved or maintained first considered with their available resources.

As a scientific method, SITOREM process by involving expert to judge the weighted of each indicator can be assumed as the judgmental process which utilized management expertise. The results of expert judgment combined with the empirical data from the research took place will generate findings that more realistic and relevant with the theoretical background of the research as well as with the actual condition of the organizations.

SITOREM can be used as a research model for optimizing organizational resources. It can be utilized as independent method or combined with other research method in Education Management. The SITOREM results bring an idea how to derive specific recommendations to implement the research findings in optimal or economical ways in the actual organizations setting.

\section{REFERENCES}

[1] A.R. Saker and C.S. Newton. Optimization Modeling: A Practical Approach. Boca Raton, FL: CRC Press, Taylor \& Francis Group, 2008.

[2] T.R. Kelly, Optimization, an Important Stage of Engineering Design. Utah State University, Digital Common @USU, 2010.

[3] S. Hardhienata, "The Development of Scientific Identification Theory to Conduct Operation Research in Education Management", IOP Conference Series: Material Science and Engineering, vol. 166, 2017.

[4] W. Sunaryo, A.M. Basroh, and S. Hardhienata. "Optimization of Enhancement the Organizational Commitment through Developing Organizational Culture and Interpersonal Communication using Sequential Explanatory and SITOREM Method", International Journal of Recent Technology and Engineering (IJRTE), vol. 8(2S7), pp. 97101, 2019.

[5] S.P. Fauziah, T. Abdullah and W. Sunaryo, "Improvement of Organizational Citizenship Behavior through Personality, Interpersonal Communication, and Organizational Justice", International Journal of Managerial Studies and Research (IJMSR), vol. 7, issue 12, pp. 47-53, 2019.

[6] A. Rosandi, S. Hardhienata, W. Sunaryo, and M.Z. Arifin, "Improvement of Organizational Citizenship Behavior (OCB) through Strengthening Transformational Leadership, Job Satisfaction, and SelfEfficacy”, Opcion, Año 35, Especial No 21, pp. 2899-2921, 2019.

[7] M.E.U. Djami, S. Hardhienata, and M. Tukiran, "Improvement of Job Satisfaction through Transformational Leadership, Personality, and Achievement Motivation by Using Scientific Identification Theory of Operation Research in Education Management (SITOREM)", International Journal of Managerial Studies and Research, vol. 7, issue 4, pp. 62-70, 2019.

[8] A. Dasmin, T. Abdullah, and S. Setyaningsih, "Improving Teacher Performance through Organizational Culture, Transformational Leadership and Work Motivation", International Journal of Managerial Studies and Research (IJMSR), vol. 8, issue 7, pp. 33-40, 2020.

[9] W. Sunaryo and S. Setyaningsih, Penulisan Proposal Penelitian Menggunakan Pendekatan Korelasional dan Analisis SITOREM. Bogor: Program Pascasarjana Universitas Pakuan, 2018. 